\title{
Comparative Study of Sex Selection in Assisted Reproductive Technology's Regulation Between Indonesia and England
}

Perbandingan Hukum Pemilihan Jenis Kelamin dengan Reproduksi Bantuan di Indonesia dan Inggris

\author{
Rani Tiyas Budiyanti \\ email: ranitiyas@live.undip.ac.id \\ Faculty of Public Health, Diponegoro University, Semarang \\ Anggita Doramia Lumbanraja \\ email: anggitalumbanraja@live.undip.ac.id \\ Faculty of Law, Diponegoro University, Semarang
}

\begin{abstract}
Sex selection through assisted reproduction technology can be done by sperm sorting and Pre-Implantation Genetic Diagnosis (PGD) However, there were different regulations in many countries. This study aims to determine the regulation of sex selection with assisted reproductive technology in Indonesia and its comparison with other countries, namely the United Kingdom. This research was a normative study with a comparative and statue approach. Based on research, regulations regarding sex selection with assisted reproduction in Indonesia have been regulated in Government Regulation No. 61 of 2014 concerning Reproductive Health. Indonesia legalizes sex selection by assisting reproduction for second and subsequent children without differentiating the underlying medical and non-medical reasons. The sex selection method regulated in the regulation is the sperm sorting method, whereas, for the PGD method. It has not been regulated further, Indonesia does not yet have further regulations regarding the implementation of sex selection by assisting reproduction along with negative excesses that can occur. Whereas the UK legalizes the selection of sex by assisting reproduction for serious medical reasons and does not allow for non-medical reasons. The sex selection method regulated in the regulation is $P G D$. Organizing sex selection in the UK will be done after obtaining a license from the Human Fertilization and Embryology Authority (HFEA).
\end{abstract}

Keywords: comparative law, sex selection, assisted reproductive technology.

Abstrak: Pemilihan jenis kelamin melalui teknologi reproduksi bantuan dapat dilakukan dengan pemisahan sperma ( sperm sorting ) maupun Pre-Implantation Genetic Diagnosis (PGD) Meskipun demikian, regulasi di beberapa negara berbeda-beda. Penelitian ini bertujuan untuk mengetahui regulasi mengenai pemilihan jenis kelamin dengan reproduksi bantuan di Indonesia dan perbandingannya dengan negara lain yaitu Inggris. Penelitian ini merupakan penelitian normatif dengan pendekatan komparatif dan peraturan perundangundangan. Berdasarkan penelitian, regulasi mengenai pemilihan jenis kelamin dengan reproduksi bantuan di Indonesia telah diatur dalam Peraturan Pemerintah Nomor 61 tahun 2014 tentang Kesehatan Reproduksi. Indonesia melegalkan pemilihan jenis kelamin dengan reproduksi bantuan untuk anak kedua dan selanjutnya tanpa membedakan alasan medis dan non medis yang mendasarinya. Metode pemilihan jenis kelamin yang diatur dalam regulasi adalah metode sperm sorting sedangkan untuk metode PGD belum diatur lebih lanjut, Indonesia belum memiliki peraturan lanjutan mengenai penyelenggaraan pemilihan jenis 
kelamin dengan reproduksi bantuan beserta ekses negatif yang dapat terjadi. Sedangkan Inggris melegalkan pemilihan jenis kelamin dengan reproduksi bantuan untuk alasan medis yang serius dan tidak mengijinkan untuk alasan non medis. Metode pemilihan jenis kelamin yang diatur dalam regulasi adalah PGD. Penyelenggaraan pemilihan jenis kelamin di Inggris akan dilakukan setelah mendapatkan lisensi dari Human Fertilization and Embriology Authority (HFEA).

Kata kunci : perbandingan hukum, pemilihan jenis kelamin, reproduksi dengan bantuan

\section{PENDAHULUAN}

Reproduksi dengan bantuan (assisted reproductive technology) merupakan salah satu teknologi yang berkembang di bidang kesehatan. Teknologi ini merupakan penanganan terhadap gamet (ovum atau sel telur, sperma) serta embrio (konsepsi hasil pertemuan ovum dan sperma) sebagai upaya untuk mendapatkan kehamilan di luar cara alamiah, tidak termasuk kloning atau duplikasi manusia. ${ }^{1}$ Reproduksi dengan bantuan dapat memberi peluang kepada pasangan yang sukar memiliki keturunan atau infertil ${ }^{2}$ untuk memiliki anak sehingga hak reproduksinya dapat terjamin.

Hak reproduksi untuk melanjutkan keturunan merupakan salah satu hak yang dijamin oleh undang-undang sebagaimana tercantum dalam Pasal 28B Undang-Undang Dasar 1945. Hak tersebut juga merupakan hak asasi manusia sebagaimana yang tercantum dalam Pasal 10 ayat (1) Undang-Undang Hak Asasi Manusia Nomor 39 tahun 1999 tentang Hak Asasi Manusia (UU HAM) yang menyebutkan bahwa setiap orang yang berhak membentuk keluarga dan melanjutkan keturunan melalui perkawinan yang sah. Berdasarkan Pasal 2 UU No. 1 Tahun 1974 tentang Perkawinan (UU Perkawinan), suatu perkawinan yang sah adalah perkawinan yang dilakukan menurut hukum maupun agama atau keyakinannya masing-masing, dengan menitikberatkan pada unsur pencatatan perkawinan sebagai bukti legalitas suatu perkawinan yang sah.

Seorang wanita memiliki hak khusus yang melekat pada dirinya yakni fungsi reproduksinya dilindungi oleh hukum sebagaimana di atur di dalam Pasal 49 ayat (3) UU HAM. Lebih lanjut pada Penjelasan Pasal 49 ayat (2) UU HAM memberikan pengertian dan batasan mengenai perlindungan khusus terhadap fungsi reproduksi pada wanita yakni meliputi pelayanan kesehatan yang berkenaan dengan haid, hamil, melahirkan dan pemberian kesempatan bagi Ibu untuk dapat menyusui anaknya. Oleh karena itu senafas dengan Penjelasan Pasal 49 ayat (2) UU HAM, UU No 36. Tahun 2009 tentang Kesehatan mengatur pula tentang penyelenggaraan upaya kesehatan reproduksi yang termakhtub pada Pasal 48 dalam undang-undang tersebut.

Setiap pasangan suami-isteri yang terikat perkawinan yang sah dijamin haknya oleh hukum untuk menjalani kehidupan reproduksi dan kehidupan seksual yang sehat, aman serta bebas dari paksaan dan/atau kekerasan dengan pasangannya, dengan memperhatikan dan menghormati nilai-nilai luhur yang tidak merendahkan martabat manusia berdasarkan norma

\footnotetext{
1 Subiyanto, Muchsin Jaffar, Yuslam EF. Etika dalam Teknologi Reproduksi Manusia. Simposium Mencegah Konflik Etik, Pertemuan Ilmiah Tahunan (PIT) XIII POGI. Malang, 28 Juni- 3 Juli 2002.

${ }^{2}$ Infertilitas diartikan sebagai suatu keadaan yang mana pasangan suami istri telah menikah selama 1 tahun dan melakukan hubungan secara rutin tetapi belum dikarunia anak.
} 
SOEPRA Jurnal Hukum Kesehatan

TERAKREDITASI RISTEKDIKTI Peringkat 4

ISSN:2548-818X (media online) Vol. 6 (1) Juni 2020

agama yang berlaku. Hal ini sebagaimana diatur di dalam Pasal 72 UU No 36 Tahun 2009 Tentang Kesehatan.

Di kalangan masyarakat Indonesia saat ini kerap ditemui permasalahan kesehatan yang berhubungan dengan fungsi reproduksi yang melanda kehidupan perkawinan suami-isteri. Kasus infertilitas atau ketidaksuburan yang menyebabkan kemandulan menyebabkan pasangan suami-isteri tidak dapat memiliki keturunan. Hal ini sering memicu berbagai polemik dalam kehidupan rumah tangga. Namun perkembangan teknologi kesehatan khususnya di bidang reproduksi memberikan secercah harapan bagi suami isteri untuk mendapatkan keturunan meskipun terkendala dengan kasus infertilitas. Sebagaimana telah dikemukakan di atas bahwa bioteknologi ini disebut sebagai Reproduksi dengan bantuan atau yang disebut dengan Assisted Reproductive Technology (ART). Assisted Reproductive Technology (ART) dapat dilakukan dengan beberapa teknik In-Vitro Fertitlisation yakni dengan Frozen Embryo Transfer (FER), egg donation (ED), Intra-uterine Insemintations (IUIs), donor sperm (IUI-D) and Husband's sperm (IUI-H)3.

Ketentuan mengenai Reproduksi dengan bantuan diatur di dalam UU No. 36 Tahun 2009 tentang Kesehatan dan PP No. 61 Tahun 2014 tentang Kesehatan Reproduksi. Reproduksi dengan cara bantuan dapat dilakukan dengan prosedur dan ketentuan yang dilindungi oleh peraturan perundang-undangan tersebut. Menurut Pasal 127 ayat (1) dan (2) Undang-Undang No. 36 tahun 2009 tentang Kesehatan, upaya kehamilan di luar cara alamiah dilakukan oleh pasangan suami istri dengan ketentuan hasil pembuahan berasal dari sperma dan ovum (sel telur) suami istri yang bersangkutan dan ditanam dalam rahim istri dimana ovum berasal. Pada Pasal 1 angka 10 PP No. 61 Tahun 2014 memberikan definisi yang jelas mengenai Reproduksi dengan Bantuan atau Kehamilan di Luar Cara Alamiah merupakan cara yang ditempuh oleh pasangan suami isteri di luar cara alamiah tanpa melalui suatu hubungan seksual apabila tidak membuahkan hasil (tidak menghasilkan keturunan setelah berhubungan seksual). PP No. 61 Tahun 2014 tentang Kesehatan Reproduksi ini memberikan Batasan bahwa Reproduksi dengan Bantuan hanya dapat dilakukan oleh pasangan suami isteri yang terikat perkawinan yang sah dan mengalami ketidaksuburan, hal ini sebagaimana diatur di dalam Pasal 40 dalam Peraturan Permerintah ini.

Upaya kehamilan dengan bantuan dilakukan oleh tenaga kesehatan yang memiliki keahlian dan kewenangan dan dilakukan di fasilitas pelayanan kesehatan tertentu. Reproduksi dengan bantuan tidak hanya membuka peluang untuk membantu pasangan infertil untuk mendapatkan keturunan, tetapi juga dapat digunakan untuk mendapatkan anak sesuai dengan jenis kelamin yang diinginkan. PP No. 61 Tahun 2014 tentang Kesehatan Reproduksi (PP Kesehatan Reproduksi) mengatur mengenai Reproduksi dengan Bantuan untuk tujuan memilih jenis kelamin anak (sex selection). Pasal 44 PP Kesehatan Reproduksi memberikan batasan dan larangan terhadap praktik ini, reproduksi dengan bantuan dengan tujuan memilih jenis kelamin anak hanya diperuntukan untuk anak kedua dan selanjutnya, maksudnya adalah pemilihan jenis kelamin anak hanya dapat dilakukan sebelum terjadinya proses pembuahan dengan cara memisahkan sel sperma $x$ dan y (Penjelasan Pasal 44 PP Kesehatan Reproduksi).

\footnotetext{
3 A. Nyboe Andersen, L. Gianaroli, R. Felberbaum, J. de Mouzon, dan K.G. Nygren. 2001. Assisted Reproductive Technology in Europe, 2001. Results Generated from European Registers by ESHRE. Human Reproduction Vol. 20, No. 5, pp 1158-1176, January 21, 2005. Doi : 10.1093/humrep/deh755
} 
Pada prinsipnya, alasan pemilihan jenis kelamin dapat disebabkan karena alasan medis maupun non medis ${ }^{4}$. Faktor sosial, ekonomi, dan agama merupakan alasan non medis yang telah terjadi sejak berpuluh-puluh tahun yang lalu. Preferensi orang tua terhadap jenis kelamin tertentu juga dapat menjadi alasan seperti yang terjadi di negara India serta China. ${ }^{5}$ Hal ini semakin kental di kalangan masyarakat patrilineal, yang mana anak laki-laki dianggap memiliki kharisma, dapat membantu beban orang tua secara ekonomi, serta dapat memimpin peribadatan. ${ }^{6}$ Kecenderungan terhadap anak laki-laki menjadikan munculnya isu diskriminasi terhadap wanita. Terdapat beberapa laporan yang menyebutkan tingginya aborsi, pembunuhan bayi perempuan serta peningkatan sex birth ratio (SBR) ${ }^{7}$ hingga mencapai 115:100. Hal ini diperparah dengan munculnya teknologi yang dapat mendeteksi jenis kelamin selama kehamilan pada trimester pertama dan kedua seperti ultrasonografi , amniosintesis, Chorionic Villus Sampling (CVS), dan Maternal Blood Test. ${ }^{8}$

Alasan pemilihan jenis kelamin karena faktor non medis juga dilatarbelakangi oleh keinginan orang tua untuk memiliki anak dengan jenis kelamin yang lengkap baik laki-laki maupun perempuan (family balancing). ${ }^{9}$

Pemilihan jenis kelamin karena alasan non medis adalah isu yang paling kontroversial di dunia bioetik dewasa ini. Alasan non medis didasarkan pada asumsi-asumsi yang bertumbuh di masyarakat yang justru menimbulkan ketimpangan gender dan mengurangi rasio natural sex. Di dunia bioetik, alasan-alasan tersebut sulit untuk diterima ${ }^{10}$.

Dengan munculnya teknologi reproduksi bantuan, pemisahan kromosom pada sperma maupun skrining genetik dapat dilakukan pada bakal janin sebelum ditanamkan dalam rahim. Beberapa jenis penyakit genetik yang terkait dengan kromosom $X$ dan berhubungan dengan jenis kelamin anak seperti Thallasemia dan Dunchen Muscular Distrophy mulai menjadi pertimbangan. ${ }^{11} \mathrm{Hal}$ inilah yang menjadi alasan pemilihan jenis kelamin dengan alasan medis.

Pada pemilihan jenis kelamin dengan reproduksi bantuan, metode yang dapat digunakan adalah pemisahan sperma (sperm sorting) dan metode Pre Implantation Genetic Diagnosis (PGD). Pada sperm sorting, kromosom ${ }^{12} \mathrm{X}$ dan $\mathrm{Y}$ dalam sperma akan dipisahkan dengan sinar laser. Perbedaan kedua kromosom tersebut dapat diketahui melalui fluorosensi yang muncul. Kromosom X memiliki jumlah DNA (deoxyribonucleic acid) 2,8\% lebih banyak

\footnotetext{
${ }^{4}$ Ethics Committee of the American Society for Reproductive Medicine. 2015. Use of reproductive technology for sex selection for nonmedical reasons. Fertility and Sterility Journal, Volume 103, Issue 6, June 2015, pp. 1418-1422. https://doi.org/10.1016/j.fertnstert.2015.03.035

5 Simon Parry. 2005. Shortage of Girls Causes China to Criminalise Selective Abortion, Telegraph (London)

${ }^{6}$ Neil Samson Katz. 2006. Abortion in India: Selecting by Gender, WASH. POST, For a discussion of the motivations underlying sex selection in China and India.

7 Sex Birth Ratio (SBR) adalah rasio bayi laki-laki per 100 bayi perempuan. Normal rasio adalah 102-108.

${ }^{8}$ Abby Lipman, Note. Prenatal Genetic Testing and Screening: Constructing Needs and Reinforcing Inequities, 17 Am.J.L \& MED,.15.24. 1991

9 Marcy Darnovsky. 2004. Revisiting Sex Selection: The Growing Popularity of New Sex Selection Methods Revives an Old Debate, GENEWATCH

${ }^{10}$ E. Dahl, M. Beutel, B. Brosig, S. Grussner, Y. Stobel-Richter ,H.R. Tinneberg · Elmar Brahler. 2006. Social sex selection and the balance of the sexes: Empirical evidence from Germany, the UK, and the US. Journal of Assisted Reproduction and Genetics, Volume 23, Issue 7-8, pp 311-318. DOI 10.1007/s10815-006-9064-y

${ }^{11} \mathrm{lbid}$

${ }^{12}$ Kromosom adalah struktur dalam sel yang mengandung informasi genetik.
} 
dibandingkan kromosom $Y$ sehingga penampakannya lebih cerah dan tebal. ${ }^{13}$ Pemisahan kromosom $\mathrm{X}$ dan $\mathrm{Y}$ juga dapat dilakukan dengan gradien albumin. ${ }^{14}$

Kromosom yang akan digunakan diselaraskan dengan jenis kelamin yang dikehendaki. Jika yang diinginkan adalah anak perempuan maka yang diambil adalah kromosom $\mathrm{X}$ sedangkan jika preferensi adalah anak laki-laki maka yang diambil adalah kromosom Y. Kromosom tersebut kemudian akan dipertemukan dengan kromosom $\mathrm{X}$ dari sel telur melalui teknologi reproduksi buatan yang dikehandaki, baik melalui bayi tabung (IVF) ataupun reproduksi dengan bantuan lainnya. Peluang pemilihan jenis kelamin dengan metode ini sebesar 75 hingga $80 \% .^{15}$

PGD (Pre implantation Genetic Diagnosis) merupakan teknik screening genetik embrio yang akan ditanam pada teknologi reproduksi bayi tabung/ in vitro fertilization (IVF). Pada PGD, teknik IVF adalah intracytoplasmic sperm injection (ICSI) yaitu single sperma diambil dan disuntikkan ke dalam sel telur hingga menjadi embrio. ${ }^{16}$ Embrio yang diperoleh akan dikembangkan dalam laboratorium selama tiga hari menjadi delapan sel. Satu atau dua sel tersebut kemudian diambil untuk sampel in vitro yang disebut dengan embrio biopsi. ${ }^{17}$ Embrio biopsi tersebut akan dianalisis dan diidentifikasi DNA untuk kemudian ditentukan embrio dengan jenis kelamin yang diharapkan untuk ditanam di dalam rahim.

Berbeda dengan sperm sorting yang melakukan pemisahan kromosom sebelum pembuahan, PGD memilah jenis kelamin yang diinginkan setelah proses pembuahan atau terjadi embrio sehingga angka keberhasilan teknologi ini cukup tinggi bahkan mendekati $100 \% .{ }^{18}$ PGD juga dapat digunakan untuk screening genetik embrio, sehingga hanya embrio yang akan ditanam di dalam rahim. Teknik ini lebih mahal dibandingkan dengan pemisahan sperma dan saat ini sudah mulai dikembangkan di Indonesia.

\section{PERUMUSAN MASALAH}

Berdasarkan Peraturan Pemerintah Nomor 61 tahun 2014 tentang Kesehatan Reproduksi, Indonesia memperbolehkan pemilihan jenis kelamin pada anak kedua dan selanjutnya tanpa membedakan permasalahan medis dan non medis. Hal tersebut perlu ditilik kembali terutama pemilihan jenis kelamin karena alasan non medis. Perbandingan regulasi dengan negara lain diperlukan mengingat pemilihan jenis kelamin karena alasan non medis dilarang di sebagian besar negara di dunia. Pada penelitian ini dilakukan perbandingan hukum pemilihan jenis kelamin antara Indonesia dengan Inggris.

\footnotetext{
${ }^{13}$ Human Fertilisation and Embriology Authority. Sex Selection :Choice and responsibility in human reproduction. 2003.

${ }^{14} \mathrm{lbid}$

${ }^{15} \mathrm{lbid}$

${ }^{16}$ Taylor A. A guide to preimplatation genetic diagnosis. Galton Institute Occasional Paper, Third Series no.1; 2008

$17 \mathrm{lbid}$

${ }^{18} \mathrm{lbid}$
} 


\section{METODE PENELITIAN}

Penelitian ini adalah penelitian normatif dengan pendekatan komparatif dan perundangundang-undangan. Bahan hukum primer diperoleh dari peraturan perundang-undangan yang berlaku yaitu Undang-Undang Dasar Negara Republik Indonesia Tahun 1945, Undang-Undang Nomor 1 Tahun 1974 tentang Perkawinan, Undang-Undang No. 39 Tahun 1999 tentang Hak Asasi Manusia, Undang-Undang Nomor 36 tahun 2009 tentang Kesehatan, dan Peraturan Pemerintah Nomor 61 tahun 2014. Sedangkan bahan hukum sekunder diperoleh dari jurnal, buku, artikel yang berhubungan dengan pemilihan jenis kelamin dan regulasi yang mengaturnya.

\section{PEMBAHASAN}

1. Peraturan Hukum Mengenai Pemilihan Jenis Kelamin dengan Reproduksi Bantuan di Indonesia

Di kalangan masyarakat unilateral (patrilineal atau matrilineal) di Indonesia yang didasarkan pada aspek genealogis (keturunan) masih dibayangi oleh preferensi yang besar terhadap salah satu jenis kelamin sebagai keturunan yang akan meneruskan garis keturunan dikarenakan alasan-alasan yang berdasarkan adat istiadat yang sudah turun temurun ${ }^{19}$. Namun, peraturan perundang-undangan mengenai pemilihan Jenis Kelamin dengan Reproduksi Bantuan di Indonesia masih mengacu pada PP No. 61 Tahun 2014 tentang Kesehatan Reproduksi dengan peraturan di tataran teknis yakni Peraturan Menteri Kesehatan Nomor 43 tahun 2015 tentang Penyelenggaraan Pelayanan Reproduksi dengan Bantuan atau Kehamilan di Luar Cara Alamiah. Perkembangan regulasi mengenai isu ini masih belum mengalami pergerakan yang signifikan. Cukup banyak isu-isu mengenai reproduksi dengan bantuan karena alasan pemilihan jenis kelamin, yang belum diakomodir oleh produk regulasi di Indonesia.

Persyaratan penggunaan teknologi reproduksi bantuan tercantum dalam Pasal 41 ayat (a) dan (b) Peraturan Pemerintah Nomor 61 tahun 2014 tentang Kesehatan Reproduksi yaitu teknologi reproduksi bantuan ditujukan kepada pasangan infertil yang sebelumnya telah mendapatkan terapi infertilitas tetapi belum berhasil dan dilakukan atas indikasi medis. Akan tetapi, alasan pemilihan jenis kelamin baik medis maupun non medis tidak diatur dalam peraturan tersebut. Peraturan tersebut hanya memperbolehkan pemilihan jenis kelamin dengan reprodiksi bantuan pada anak kedua dan selanjutnya seperti yang tercantum dalam Pasal 44 Peraturan Pemerintah Nomor 61 tahun 2014 tentang Kesehatan Reproduksi yang berbunyi " Reproduksi dengan Bantuan atau Kehamilan di Luar Cara Alamiah dilarang untuk tujuan memilih jenis kelamin anak yang akan dilahirkan kecuali dalam hal pemilihan jenis kelamin untuk anak kedua dan selanjutnya."

Dalam penjelasan pasal 44 Peraturan Pemerintah Nomor 61 tahun 2014 disebutkan bahwa peraturan mengenai pemilihan jenis kelamin tersebut terbatas pada sperm sorting yaitu dengan cara memisahkan kromosom X dan Y. Prosedur pemilihan jenis kelamin dengan metode Pre Implantation Genetic Diagnosis (PGD) belum diatur dalam peraturan ini.

Peraturan mengenai Penyelenggaraan Reproduksi Bantuan juga diatur dalam Peraturan Menteri Kesehatan Nomor 43 tahun 2015. Dalam peraturan tersebut dijelaskan bahwa

19 Soerojo Wignjodipoero. 1988. Pengantar dan Asas-Asas Hukum Adat. Jakarta, PT. Lawang Kencana Indah, halaman 109-110 
reproduksi berbantu hanya dapat diberikan kepada pasangan suami istri yang terkait perkawinan yang sah sebagai upaya akhir untuk memperoleh keturunan serta berdasarkan pada indikasi medis. Pelayanan hanya dilakukan di rumah sakit umum (RSU) serta rumah sakit khusus ibu dan anak yang memenuhi persyaratan ketenagaan, administrasi dan manajemen, serta sarana, prasarana, dan peralatan.

Meskipun demikian, penyelenggaraan pemilihan jenis kelamin dengan teknologi reproduksi berbantu dapat menimbulkan ekses-ekses negatif diantaranya adalah munculnya aborsi selektif dan permasalahan embrio sisa.

Ketika jenis kelamin anak yang berkembang dalam rahim berbeda dengan preferensi yamg diharapkan, maka aborsi selektif karena jenis kelamin dapat terjadi. Peluang kegagalan tersebut masih dapat terjadi pada metode dengan sperm sorting maupun PGD. Meskipun kegagalan karena PGD jarang ditemui.

Aborsi merupaksn tindakan prngakhiran kehamilan yang dilakukan ketika janin berada dalam kandungan sebelum usia 20 minggu. Di Indonesia, permasalahan mengenai aborsi telah diatur dalam Pasal 75 ayat (2) Undang-Undang No. 36 tahun 2009 tentang Kesehatan dan Pasal 31 ayat (1) dan (2) Peraturan Pemerintah No 61 tahun 2014 tentang Kesehatan Reproduksi. Dalam peraturan tersebut disebutkan bahwa aborsi diperbolehkan sebelum usia 6 minggu untuk alasan medis dan perkosaan. Indikasi kedaruratan medis berlaku untuk hal yang mengancam jiwa, fisik, dan mental ibu, serta cacat atau abnormalitas yang berat. Keputusan final dilakukan aborsi harus didahului oleh panel antara 2 dokter dan ahli lain.

Meskipun belum terdapat regulasi spesifik, tetapi aborsi selektif karena pemilihan jenis kelamin terutama karena alasan non medis dilarang selayaknya abortus kriminal. Tindakan tersebut dapat dikenai sanksi pidana paling lama 10 tahun dan denda paling banyak 1 miliar seperti yang tercantum dalam Pasal 75 ayat (3) Undang-Undang No.36 tahun 2009 tentang Kesehatan.

Meskipun demikian, aborsi selektif karena pemilihan jenis kelamin dengan alasan medis menjadi dilema tersendiri. Terutama jika telah ada campur tangan dalam penentuan jenis kelamin dengan teknologi tertentu. Belum ada regulasi yang menyatakan bahwa aborsi selektif karena pemilihan jenis kelamin dengan alasan medis diperbolehkan.

Selain aborsi selektif, ekses negatif yang dapat terjadi adalah permasalahan embrio sisa. Pada saat pembuahan, jumlah sel telur yang dibuahi dan menjadi embrio dalam reproduksi bantuan lebih dari 1 embrio. Padahal, hanya kurang lebih 3 embrio yang boleh ditanam dalam rahim untuk mengurangi resiko kegagalan dan multiple pregnancy yang dapat memberatkan pihak ibu. Pada prinsipnya terdapat beberapa alternatif dalam perlakuan terhadap embrio sisa yaitu dengan disimpan/dibekukan, didonorkan kepada pasangan lain, digunakan untuk penelitian, dan dihancurkan.

Penyimpanan terhadap embrio sisa diatur dalam Pasal 43 ayat (1) Peraturan Pemerintah No 61 tahun 2014 tentang Kesehatan Reproduksi dengan ketentuan bahwa Kelebihan embrio hasil pembuahan di luar tubuh manusia (fertilisasi invitro) yang tidak ditanamkan pada rahim harus disimpan sampai lahirnya bayi hasil reproduksi dengan bantuan atau kehamilan di luar cara alamiah.

Pada ayat (2) disebutkan bahwa penyimpanan kelebihan embrio tersebut dapat diperpanjang setiap 1 tahun atas keinginan pasangan suami istri. Jika pasangan suami istri 
tidak memperpanjang penyimpanan, embrio akan disimpan dalam jangka waktu 2 tahun seperti yang tercantum dalam Pasal 14 ayat (3) Peraturan Menteri Kesehatan Nomor 43 tahun 2015 tentang Penyelenggaraan Pelayanan Reproduksi dengan Bantuan atau Kehamilan di Luar Cara Alamiah.

Permasalahan yang dapat muncul adalah jika semakin lama bank embrio semakin menumpuk disertai tingginya biaya penyimpanan embrio. Selain itu, jika pasangan suami istri tersebut salah satunya meninggal atau bercerai, maka embrio tersebut harus dihancurkan. Penggunaan embrio sisa untuk donor dilarang di Indonesia sebagaimana yang tercantum dalam pasal 43 ayat (3) Peraturan Pemerintah Nomor 61 tahun 2014 tentang kesehatan reproduksi yang melarang penanaman embrio pada rahim perempuan lain. Selain itu pada pasal 40 ayat (1) dan (2) peraturan tersebut disebutkan reproduksi dengan bantuan hanya dapat dilakukan oleh pasangan suami istri yang sah, dengan hasil pembuahan sperma dan ovum yang berasal dari suami istri yang bersangkutan dan ditanamkan dalam rahim istri darimana ovum berasal.

Embrio sisa juga dapat digunakan sebagai penelitian sebagaimana yang tercantum dalam Pasal 3 ayat (2), (3), dan (4) Permenkes Nomor 833/Menkes/Per/IX/2009 tentang Penyelenggaraan Pelayanan Sel Punca, dengan persetujuan orang tua pemilik embrio secara sukarela.

Hal terakhir yang menjadi alternatif adalah penghancuran embrio. Hal ini seringkali menimbulkan polemik dan dilema karena embrio merupakan calon janin yang dapat hidup. Beberapa pihak mengatakan bahwa embrio adalah calon adanya makhluk hidup yang harus dihormati hak hidupnya, sebaliknya beberapa pihak lain mengatakan bahwa penghancuran tersebut memiliki berbagai tujuan termasuk untuk menghindari penyalahgunaan embrio.

Peluang untuk terjadinya pelanggaran dapat diakibatkan karena adanya praktek jual beli embrio entah untuk donor, penelitian, ataupun stem cell. Hal tersebut dilarang dalam Pasal 2 ayat (2) Permenkes Nomor 833/Menkes/Per/IX/2009 tentang Penyelenggaraan Pelayanan Sel Punca.

2. Peraturan Hukum Mengenai Pemilihan Jenis Kelamin dengan Reproduksi Bantuan di Inggris

Inggris merupakan negara dengan sistem hukum Common Law dimana peran juri sangat besar di dalamnya. Penentuan hukum pemilihan jenis kelamin dengan teknologi reproduksi bantuan di Inggris juga didasarkan pada aspirasi publik.

Pada tahun 2002-2003 didapatkan data bahwa, pemilihan jenis kelamin dengan pemisahan sperma karena alasan non medis : $13,24 \%$ responden setuju, $82 \%$ tidak setuju, dan $4,7 \%$ tidak memberikan argumennya. Sedangkan pemiihan jenis kelamin dengan menggunakan PGD karena alasan non medis : 11,71\% responden setuju, 82,85 tidak setuju, dan 5,44\% tidak memberikan respon. Besarnya angka yang tidak setuju dengan PGD karena alasan non medis dikarenakan masyarakat di Inggris tidak terlalu mempermasalahkan jenis kelamin anak yang akan dilahirkan. Sebuah survey yang dilakukan oleh E. Dahl, et.al. memperlihatkan hasil yakni sebesar $74 \%$ responden warga Inggris mengakui tidak peduli 
dengan jenis kelamin anak pertama mereka, sedangkan $16 \%$ responden mengingini anak pertama laki-laki dan $10 \%$ responden yang mengingini anak pertama perempuan ${ }^{20}$.

Lebih lanjut, Inggris mengatur regulasi mengenai pemilihan jenis kelamin dengan reproduksi bantuan dalam Human Fertilization and Embriology Act (HFEA) dan membagi dua alasan pemilihan jenis kelamin yaitu medis dan non medis. Pada peraturan HFE Act 2008 disebutkan bahwa: ${ }^{21}$

"A licence...cannot authorise the testing of an embryo, except for one or more of the following purposes: In a case where there is a particular risk that any child will have or develop A gender related serious physical or mental disabilitty $A$ gender related serious illness, or Any other gender related serious medical condition, establishing the sex of the embryo"

Dalam regulasinya, HFEA hanya memperbolehkan pemilihan jenis kelamin karena alasan medis dan hanya dilakukan pada penyakit genetik atau X-linked disease yang serius, penyakit mental yang serius, dan penyakit lain yang terkait dengan jenis kelamin yang serius.

Beberapa penyakit yang tidak mengakibatkan permasalahan serius seperti buta warna tidak diperbolehkan, sedangkan Duchene Muscular Distrophy merupakan penyakit yang serius yang diperbolehkan untuk dilakukan sex selection. ${ }^{22}$

HFEA memiliki daftar penyakit yang diperbolehkan untuk dilakukan PGD dan sex selection serta daftar penyakit yang dipertimbangkan untuk dapat dilakukan PGD dan sex selection Menurut HFEA 8th Code of Practice, pemilihan jenis kelamin tidak ditujukan untuk alasan non medis (sosial). ${ }^{23}$ HFEA meminta rumah sakit dan klinik yang melakukan prmilihan jenis kelamin dengan reproduksi bantuan mengajukan ijin. Prosedur ini dilakukan demi keamanan pasien dan anak yang akan dilahirkan melalui teknologi reproduksi buatan.

Berbeda dengan Indonesia, HFEA di Inggris tidak menganjurkan pemilihan jenis kelamin dengan sperm shorting karena faktor keberhasilan dan keamanan yang belum terjamin. Sebaliknya, HFEA hanya menyarankan pemilihan jenis kelamin dengan PGD dan untuk alasan medis yang serius.

HFEA Code of Practice menerapkan aturan yang cukup ketat terhadap klinik penyelenggara pemilihan jenis kelamin dengan teknologi reproduksi buatan. Persyaratan yang diterapkan diantaranya adalah Fasilitas pelayanan kesehatan tersebut harus menggunakan teknik yang dianjurkan oleh HFEA yaitu dengan PGD untuk alasan medis serius, telah melakukan pemeriksaan menyeluruh terhadap prospektif anak yang akan dilahirkan sebelum diberikan perlakuan, pelaksanaan informed consent yang menyeluruh terhadap pasangan yang akan mendapatkan perlakuan, pemberisn konseling dan pertimbangan terhadap efek samping atau segala kemungkinan yang terjadi akibat tindakan tersebut, pencatatan inormasi yang telah disampaikan terhadap pasangan atau pasien, serts pemeriksaan tahunan yang sksn dilakukan kepada dokter, staf, rekam medis, dan keseluruhan tenaga kesehatan yang terlibat dalam pelayanan tersebut.

\footnotetext{
${ }^{20}$ E. Dahl, et.al., loc.cit.

${ }^{21}$ Human Fertilization and Embriology Act. 2008. www.legislation.gov.uk

$22 \mathrm{lbid}$

23 HFEAs 8th Code of Practice. 2009. www.hfea.gov.uk
} 
Seperti halnya di Indonesia, dalam permasalahan mengenai ekses yang terjadi akibat pemilihan jenis kelamin, Inggris memiliki peraturan tersendiri mengenai aborsi selektif dan permasalahan embrio sisa. Dalam HFEA Act telah dijelaskan secara rinci bahwa alasan pemilihan jenis kelamin yang diperbolehkan adalah pemilihan jenis kelamin karena alasan medis serius dan menggunakan metode PGD dengan tingkat keberhasilan mendekati 100\% sehingga akan meminimalkan resiko sex-selective abortion.

Menurut The Abortion Act 1967, aborsi di Inggris diperbolehkan hingga usia kehamilan berusia 24 minggu. Akan tetapi jika kehamilan tersebut beresiko terhadap hidup wanita, abnormalitas janin, serta resiko pada kesehatan fisik dan mental wanita maka aborsi dapat dilakukan pada usia berapapun. Faktor sosioekonomi juga dilegalkan sebagai salah satu alasan aborsi. Pada pelaksanaannya, tindakan aborsi harus didahului dengan konseling dan mendapat persetujuan dan pernyataan oleh 2 dokter bahwa aborsi tersebut dilakukan atas indikasi medis. Akan tetapi prakteknya, banyak dokter yang memperbolehkan melakukan aborsi karena alasan sosial. Sanksi terhadap pelanggaran aborsi belum mengikat, hal tersebut diperbolehkan selama dokter memperbolehkan. ${ }^{24}$

Dalam permasalahan embrio sisa, HFEA memberikan beberapa alternatif kepada pasangan suami istri yaitu disimpan, didonorkan, disumbangkan untuk penelitian atau dihancurkan. Berbeda dengan di Indonesia, pendonoran sperma, ovum, atau embrio di negara ini adalah hal yang diperbolehkan.

\section{KESIMPULAN}

Dari pembahasan yang dilakukan, maka dapat ditarik beberapa kesimpulan yaitu:

1. Indonesia melegalkan pemilihan jenis kelamin untuk anak kedua dan selanjutnya tanpa alasan medis dan non medis, sedangkan Inggris melegalkan pemilihan jenis kelamin hanya untuk alasan medis yang serius.

2. Metode yang diatur dalam regulasi milihan jenis kelamin di Indonesia adalah metode sperm sorting sedangkan Inggris mengatur mengenai metode Pre Implantation Genetic Diagnosis (PGD). Metode sperm sorting bukanlah metode yang direkomendasikan di Inggris.

3. Indonesia belum memiliki peraturan lanjutan mengenai penyelenggaraan pemilihan jenis kelamin dengan reproduksi bantuan. Pemilihan jenis kelamin di Inggris dapat dilakukan setelah mendapatkan lisensi dari HFEA, melakukan informed consent, dan menjalani konseling.

4. Belum ada aturan spesifik mengenai aborsi selektif sebagai ekses negatif dari pemilihan jenis kelamin baik di Indonesia maupun di Inggris. Pada penanganan embrio, Indonesia memperbolehkan penyimpanan, pemusnahan, dan penggunaan embrio untuk penelitian dengan persyaratan tertentu dan melarang donor. Inggris memperbolehkan penyimpanan, pemusnahan, penggunaan embrio untuk penelitian, maupun donor.

\footnotetext{
${ }^{24}$ The Abortion Act 1967. www.legislation.gov.uk
} 


\section{SARAN}

Penelitian lebih lanjut mengenai alasan atau sejarah legalisasi pemilihan jenis kelamin dengan reproduksi bantuan di Indonesia tanpa memperhatikan alasan medis dan non medis sebaiknya dilakukan. Selain itu, perlu dikaji lebih lanjut regulasi mengenai pemilihan jenis kelamin dengan reproduksi bantuan sehingga dapat diimplementasikan tanpa bertentangan dengan norma budaya, etika, dan moral yang berlaku di Indonesia.

\section{DAFTAR PUSTAKA}

A.Nyboe Andersen, L. Gianaroli, R. Felberbaum, J. de Mouzon, dan K.G. Nygren. 2001. Assisted Reproductive Technology in Europe, 2001. Results Generated from European Registers by ESHRE. Human Reproduction Vol. 20, No. 5, pp 1158-1176, January 21, 2005. Doi : 10.1093/humrep/deh755

Abby Lipman, Note. Prenatal Genetic Testing and Screening: Constructing Needs and Reinforcing Inequities, 17 Am.J.L \& MED,.15.24. 1991

Ethics Committee of the American Society for Reproductive Medicine. 2015. Use of reproductive technology for sex selection for nonmedical reasons. Fertility and Sterility Journal, Volume 103, Issue 6, June 2015, pp. 1418-1422. https://doi.org/10.1016/j.fertnstert.2015.03.035

Human Fertilisation and Embriology Authority. Sex Selection :Choice and responsibility in human reproduction. 2003.

Marcy Darnovsky. 2004. Revisiting Sex Selection: The Growing Popularity of New Sex Selection Methods Revives an Old Debate, GENEWATCH

Neil Samson Katz. 2006. Abortion in India: Selecting by Gender, WASH. POST, For a discussion of the motivations underlying sex selection in China and India

Taylor A. A guide to preimplatation genetic diagnosis. Galton Institute Occasional Paper, Third Series no.1; 2008

Simon Parry. 2005. Shortage of Girls Causes China to Criminalise Selective Abortion, Telegraph (London)

Soerojo Wignjodipoero. 1988. Pengantar dan Asas-Asas Hukum Adat. Jakarta : PT. Lawang Kencana Indah

Subiyanto, Muchsin Jaffar, Yuslam EF. Etika dalam Teknologi Reproduksi Manusia. Simposium Mencegah Konflik Etik, Pertemuan IImiaTahunan (PIT) XIII POGI. Malang, 28 Juni- 3 Juli 2002.

Undang-Undang Dasar Negara Republik Indonesia Tahun 1945

Undang-Undang Nomor 1 Tahun 1974 tentang Perkawinan

Undang-Undang Nomor 39 tahun 1999 tengan Hak Asasi Manusia

Undang-Undang Nomor 36 Tahun 2009 tentang Kesehatan

Peraturan Pemerintah Nomor 61 Tahun 2014 tentang Kesehatan Reproduksi 
SOEPRA Jurnal Hukum Kesehatan

TERAKREDITASI RISTEKDIKTI Peringkat 4

ISSN:2548-818X (media online) Vol. 6 (1) Juni 2020

Peraturan Menteri Kesehatan Nomor 43 tahun 2015 tentang Penyelenggaraan Pelayanan Reproduksi dengan Bantuan atau Kehamilan di Luar Cara Alamiah.

Peraturan Menteri Kesehatan Nomor 833/Menkes/Per/IX/2009 tentang Penyelenggaraan Pelayanan Sel Punca

HFEA Acts 8th Code of Practice. 2009. www.hfea.gov.uK

Human Fertilization and Embriology Act. 2008. www.legislation.gov.uk

The Abortion Act 1967. www.legislation.gov.uk 